\title{
Legalization of Arak Bali in Online News Headlines: Critical Discourse Analysis
}

\author{
Nadya Inda Syartanti \\ Japanese Literature Studi Program, Universitas Brawijaya, Indonesia \\ Email: nadya.inda.sy@gmail.com
}

\begin{abstract}
In 2020, arak bali, traditional liquor from Bali, was legalized by the Governor of Bali, I Wayan Koster. This research aimed to reveal the construction of news headlines about the legalization of arak bali. Data were sourced from various online news media (detiknews.com, kompas.com, tribunnews.com), collected by selecting news headlines with the keywords arak bali and pelegalan, and analyzed using Norman Fairclough's critical discourse analysis. The results showed that the six news headlines used linguistic tools such as selected vocabulary that focused on the word legal, grammatical units that were dominated by clauses, syntactic functions dominated by the discourse's topicalization, and a form of news emphasizing the statement of the legalization of arak bali by Koster. The mindset of the Balinese towards arak bali cannot be separated from their predominant belief system, Hinduism. Meanwhile, Koster's commitment to arak bali shows his ideology, as an indigenous Balinese individual, of preserving Balinese culture and traditions. Finally, the headlines on the legalization of arak bali occurred at the situational level, with Balinese people welcoming the legalization of arak bali, resulting in Koster planning to hold an arak bali festival as a means of promoting and preserving Balinese culture.
\end{abstract}

Keywords: arak bali; critical discourse analysis; governor of Bali; legalization; online news headline

\section{INTRODUCTION}

On January 29, 2020, the Governor of Bali I Wayan Koster legalized arak bali (traditional liquor from Bali) through Governor Regulation number 1 of year 2020 regarding the Governance of Balinese Fermented and/or Distilled Liquors. I Wayan Koster's decision to issue this regulation began in 2018 after being elected as Governor of Bali for the 2018-2023 term by stating that he wanted to legalize arak bali as a traditional liquor from Bali (Mustofa, 2018a).

This statement caused controversies among the Indonesian people, who are predominantly Muslim. The pros and cons arise because of concerns about the negative impact of liquor beverages on health. It is also feared that this legalization can increase the crime rate because there are many cases of fights and murders due to liquor drinking activities. Although there is no single study that can prove the relationship between acts of violence and drinking liquor in Balinese society (Sarjana, 2020).

Behind the pros and cons, Koster gave reasons and benefits with the legalization of arak bali, namely 1) preservation of local wisdom and Balinese culture that has become part of Hindu civilization; 2) development and empowerment of arak bali through a home industry in order to improve the economy of arak bali farmers; 3 ) improving the image of Bali in the eyes of tourists so that arak bali can compete with imported fermented liquors, such as Japanese sake and Chinese wine; and 4) beneficial for body health (Mustofa, 2018a; Rizky, 2020; Sarjana, 2020). Koster's commitment and seriousness in the legalization of arak bali was increasingly demonstrated by conducting studies and research on arak bali in early 2019. Studies and research on arak bali are carried out in 
terms of the manufacturing process in order to produce the right aroma and taste (Mustofa, 2018b).

Arak bali is made from fermented coconut juice or brown rice. The production process is still carried out traditionally by community groups in the villages. Arak bali contains alcohol in varying levels between 15 and 50 percent alcohol, and prices start at IDR 20-25 thousand per bottle depending on the alcohol level. During its development, this traditional arak can be mixed with various other ingredients which make it even richer in taste. This type of parade is widely sold in tourist areas such as Canggu and Seminyak (Cinti, 2020).

However, in contrast to other liquors, arak bali is also synonymous with traditional Balinese medicine, it is even claimed to be useful as a therapy for COVID-19 patients as people without symptoms (OTG) healing rates who receive arak bali therapy reaching 80 percent (Sudut Story, 2020). Not only as a treatment, arak bali is also useful as a beauty tool, preserves skin, is used as a medicine for rheumatism and diabetes, and can even be mixed with other food ingredients (Ramadhian, 2020).

Prasetya (2020) considers the legality of arak bali as a sign that alcohol does not mean that only produces negative effects. Although alcohol does have a negative effect, the effect will appear if used in excess. When there are clear and strict rules for consumption and production, cases that occur due to alcohol can be suppressed. With strict and detailed regulations, alcohol can become a commodity of economic value for the area that manages it. Due to previously alcohol was included in the negative investment list, many producers had to sell arak bali secretly, even more so, its circulation became increasingly unstoppable. The prohibition of liquor has never been effective and has resulted in the proliferation of illegal liquor in many areas. Consumption of illegal liquor is also full of risks and eliminates the potential for economic income. Therefore, the best step is to legalize it with clear and strict rules, rather than eradicating but never being effective (Prasetya, 2020).

Several previous studies related to this research have been carried out, including Sudharma, et.al. (2020) submitting arak's design packaging that later used as a souvenir of the Museum Arak, that will be given to the tourists that visited Museum Arak of Tri Eka Buana Village; Alfianti (2018) carried out a systematic interpretation and expansion of various laws related to the regulation of traditional liquor; Fatmawati (2018) explores the tradition of drinking tuak in Tegalrejo Village, Merakurak District, Tuban Regency; Alzeer \& Hadeed (2016) reviewed the issue of ethanol in food industries; Khusnaini (2016) observes the point of view of religious leaders and community leaders on the sale and purchase of tuak in Tuban Regency, East Java; Sukadana \& Tenaya (2016) explored the effect of variations in the compression ratio on the performance of a four-stroke engine with arak bali as fuel; Panggabean (2015) analyzes the patterns and factors that drive the consumption of palm wine and health complaints that occur to tuak drinker in Lumban Siagian Jae Village; Riskiyani, et.al. (2015) examines the socio-cultural aspects of the consumption of tuak in North Toraja Regency; and Indrayati (n.d.) who discussed the perception of arak producers in Merita Village, Karangasem regarding the dangers of poisoning with mixed containing methanol which can threaten health and tourism in Bali.

All previous studies discussed about traditional liquors in Indonesia with various objects of research focus, such as the problem of ethanol in the food industry (Alzeer \& Hadeed, 2016), the problem of legalizing traditional liquor (Alfianti, 2018), and the problem of the condition of arak and tuak in various regions in Indonesia, such as tuak in North Tapanuli (Panggabean, 2015), tuak in North Toraja (Riskiyani, et.al., 2015), and tuak in Tuban (Khusnaini, 2016; Fatmawati, 2018), also arak in Bali (Sudharma, et.al. (2020); Sukadana \& Tenaya (2016); Indrayati (nd). From the various objects of research focus, this study will also discuss Balinese liquor such as the three studies related to arak bali. However, among the three studies there has been no research that uses critical discourse analysis perspective. Through this perspective, this study aim to reveal the construction of news headlines about the legalization of arak bali in various online news media using Norman Fairclough's critical discourse analysis.

\section{METHODS}

The approach taken in this study is based on qualitative research assisted by a theoretical approach to critical discourse analysis by Norman Fairclough (1995). Critical discourse analysis is built based on the relationship between micro texts and the macro context of society (Darma, 2013).

The source of data in this study focuses on news headline on the legalization of arak bali delivered by the Governor of Bali, I Wayan Koster. News headlines are chosen and used because they can reveal how the news discourse is made in accordance with the three dimensions of discourse from Fairclough's critical discourse analysis. The text was issued by the online news media detiknews. com, kompas.com, and tribunnews.com. The reason for choosing these three online news media is because they 
are national online news media, not regional or local online news media specifically for certain regions. It is assumed that to observe how the national online news media present special news from one area, such as Bali regarding the legalization of arak bali.

The source of this research data was taken from January to February 2020, so that eight news headline were collected, consisting of four data from detiknews. com, two data from kompas.com, and two data from tribunnews.com. However, because the content of the news on two data from detik.com is similar to two other data from detik.com as well, the data used from detik. com is only two data. The data were collected using the observation method followed by note-taking technique as data collection methods (Mahsun, 2014) with the data subject in the form of news headlines related to the legalization of arak bali which is focused on the keywords arak bali and pelegalan (legalization).

The data analysis method was carried out by the three stages of discourse dimensional analysis in Fairclough's critical discourse analysis, namely 1) the textual dimension (microstructural) is an analysis of the text by looking at vocabulary, semantics, sentence structure, and cohesion and coherence between sentences; 2) the dimensions of the practice of discourse (mesostructural) are the practice of discourse by analyzing the processes of production, consumption, and distribution of texts; and 3 ) the socio-cultural (macrostructural) dimension is a socio-cultural practice that is analyzed using three levels, namely (a) situational, (b) institutional, and (c) social (Fairclough, 1995).

\section{FINDINGS AND DISCUSSION}

Based on the explanation above, a number of news headlines texts that discuss the legalization of arak bali were found through online news media, namely detiknews.com, kompas.com, and tribunnews.com, as shown in Table 1.

Table 1 shows that the news headlines regarding the legalization of arak bali delivered by the Governor of Bali, I Wayan Koster, has become quite viral. Arak bali, which was previously a local liquor enjoyed only by Balinese people, has now turned into a liquor that is recognized by the world. It has been proven that previously this regulation was deemed impossible to make because in Perpres No. 39 of 2004, the typical Balinese liquor referred to, namely arak, is included in the negative investment list. However, its existence is now recognized in Pergub No. 1 of 2020 which was set on 29 January 2020 by the Governor of Bali, I Wayan Koster.
Table 1. Headline News Data About Legalization of Arak Bali

\begin{tabular}{|l|c|l|}
\hline $\begin{array}{l}\text { Online News } \\
\text { Media }\end{array}$ & Data & News Headlines \\
\hline Detiknews.com & 1 & $\begin{array}{l}\text { Sah! Arak Bali dan Brem } \\
\text { Dilegalkan Gubernur Koster }\end{array}$ \\
\hline Kompas.com & 2 & $\begin{array}{l}\text { Pelegalan Arak Bali Disebut } \\
\text { Sudah Dinanti Masyarakat, Apa } \\
\text { Sebabnya? }\end{array}$ \\
\hline Kompas.com & 3 & $\begin{array}{l}\text { Ini Alasan Gubernur Legalkan } \\
\text { Arak, Tuak, dan Brem Bali }\end{array}$ \\
\hline Tribunnews.com & 4 & $\begin{array}{l}\text { Sudah jadi minuman legal, I } \\
\text { Wayan Koster Berencana akan } \\
\text { Adakan Festival Arak di Bali }\end{array}$ \\
\hline Tribunnews.com & 5 & $\begin{array}{l}\text { Pelegalan Arak di Bali } \\
\text { Ibarat Pisau Bermata Dua, } \\
\text { Kemungkinan Dampak } \\
\text { Negatifnya Harus Diantisipasi }\end{array}$ \\
\hline Detiknews.com & 6 & Menyambut Legalisasi Arak Bali \\
\hline
\end{tabular}

\section{Selected Online News Media Information}

Detiknews.com is one of national online news media founded by various journalists in Indonesia in October 1995, namely Budiono Darsono, Yayan Sopyan, and Didi Nugrahadi and Abdul Rahman. Detiknews.com is said to be the pioneer of online journalism in Indonesia. This mass media officially came under the auspices of Trans Corp on August 3, 2011, after CT Corp acquired detiknews.com.

At first, detik.com's main coverage focused on political, economic, and information technology news. Only after the political situation began to subside and the economy began to improve, detik.com also presented entertainment and sports news. From there, the desire to form detik.com was sparked, whose updates no longer use the characteristics of daily, weekly, monthly print media. What detik.com sells is breaking news. Breaking news refers to events that are currently developing, or "breaking." Breaking news usually refers to events that are unexpected, such as a plane crash or building fire (Rogers, 2019). By relying on this kind of vivid description, detik. com has become the most popular digital information site among internet users.

Kompas.com is one of national online news media under the auspices of PT Kompas Cyber Media which is part of the Kompas Gramedia (KG) group. Kompas. com was founded in 1995 under the name Kompas Online as the online edition of the Kompas Daily. In 1998 Kompas Online changed its name to Kompas.com. Kompas.com's ideology was born from the idealism of its 
founder, Jacob Oetama. Jakob Oetama's thoughts come from the concept of the existence of the press which is determined by the content and the number of readers, where the number of readers is related to the ability to manage the business, while the content is referred to as news content. Journalism introduced by Jacob Oetomo is investigative journalism with modified facts, namely reporting not only facts, but background, history, process, and casual and interactive relationships. In addition, Jakob Oetama's idea of journalism requires noble Politics of Values. Meanwhile, the media is now pragmatic and sometimes even opportunistic, especially online media. In the world of journalism, Jakob Oetama's idea is classified as a type of journalism related to how to collect facts (Rashid, 2020).

In 1987, Kompas Gramedia took over the ownership of the Sriwijaya Post Daily in Palembang, South Sumatra at the request of the Minister of Information of the Republic of Indonesia for the big newspapers to help local newspapers that were hampered by the issue of SIUPP (Press Publishing Business License). Until the end of 1987, the Regional Press Group (Persda) business unit was established under the business name of PT Indopersda Prima Media which was in charge of assisting regional newspapers in need of assistance. After taking over Sriwijaya Post, the following year Kompas Gramedia also took on various other regional newspapers, such as Serambi Indonesia in Banda Aceh, Surya Daily in Surabaya, Pos Kupang Daily (1992), and Banjarmasin Post Daily (1994).

In subsequent developments, Persda strengthened its business by establishing its own regional newspapers in almost all provinces under the Tribun brand, starting with the East Kalimantan Tribune in 2003, then followed by the East Tribune, West Java Tribune, and other Tribunbranded newspapers. Then, on March 22, 2010, Persda changed its name to Tribun Network with the aim of transforming from a striking regional impression to a colored national (Dahi, 2010).

Along with the name change, on March 22, 2010 Tribunnews.com was launched as a new online news portal that complements the websites of local newspapers managed by the Tribun Network. All news portals of the chain's newspaper is redirected into subdomains of Tribunnews.com, as well as their e-paper website. Tribunnews.com was cited by Andalas University in 2018 as the most popular nationally-hosted website in Indonesia, with 183.2 million visits per month (Perpustakaan UNAND, 2018).

\section{The Uses of Linguistic Tools in The Headline News Media}

The textual dimension is analyzed based on various linguistic tools used in the news media, especially the news about the legalization of arak bali delivered by the Governor of Bali, I Wayan Koster, where several tools mark the representation of a person's theme, namely through (1) selected diction or vocabulary, and (2) grammatical units, syntactic functions, and the form of news.

There are similar headlines, which is data (1) Sah! Arak Bali dan Brem Dilegalkan Gubernur Koster and data (3) Ini Alasan Gubernur Legalkan Arak, Tuak, dan Brem Bali. The two data do not seem to show similarities in the lexicon or vocabulary used but focus on legalized objects, namely arak, tuak, and brem. In addition, there is an affirmation of the word sah! as an imperative form of data (1).

Concerning the data in Table 1, several uses were found of the word pelegalan (legalization) as a noun such as legal (legal) on data (4) and legalisasi (legalization) on data (6) which compared to dilegalkan (legalized) as verb such as data (1), legalkan (legalizing) on data (3). Based on these data, data (1), (2), (3), (4), (5), and (6) mention arak bali as a traditional liquor that has been legalized by the Government of Bali through the Governor of Bali, I Wayan Koster as news delivered on February 5, 2020.

Based on grammatical units, data (1), (2), (4), (5) and (6) are classified as clauses, while data (3) are classified as phrases. The five data above are classified as clauses because there are the use of verbs that function as predicates. The data is the verb of dilegalkan (legalized) on data (1), the verb of disebut (are called) and the verb of dinanti (awaited) on data (2), the verb of diantisipasi (are anticipated) on data (5), which are entirely included as passive verbs. In addition, there are also active verbs, namely the verb of berencana (planning) on data (4), and the verb of menyambut (welcoming) on data (6), so that active and passive verbs are found as clauses in the five data. Passive verbs dominate the headlines in online mass media related to the legalization of arak bali conveyed by the Governor of Bali, I Wayan Koster.

In addition, it was also found that there are a syntactic function of information that serves as a topicalization of discourse such as sah! (it is legal!) on data (1); pelegalan arak bali disebut sudah dinanti masyarakat (the legalization of arak bali is said to have been awaited by the community) on data (2), sudah jadi minuman legal (it has become a legal liquor) on data (4); and pelegalan arak bali ibarat pisau bermata dua (the legalization of arak bali is like a double-edged knife) on 
the data (5). The word sah (legal; valid) in data (1) was identified as a form of confirmation of the Governor I Wayan Koster's decision which legalized arak bali. This is made clear from data (4) that the phrase sudah menjadi minuman legal (has become a legal liquor) which refers to arak bali. The legalization of arak bali has been eagerly awaited by the community as stated in data (2), where the people in question are Balinese people. However, the use of the supposition ibarat pisau bermata dua (as a doubleedged knife) in the data (5) shows that arak bali has two contradictory perspectives. Arak bali can be used as an intoxicating liquor, thus providing negative benefits that can damage the body. However, on the other hand, arak bali has positive benefits for the health of the body. Arak bali can be used as a beauty tool to preserve skin, can be used as a remedy for rheumatism and diabetes, and can even be mixed with other food ingredients (Ramadhian, 2020). The choice of words in data (1), (2), (4) and (5) is used to add information in the form of the latest facts that have been presented by news writers regarding the legalization of arak bali.

\section{Arak Bali as Part of Balinese Tradition and Culture}

One aspect of the mesostructural dimension is intertextuality and interdiscursivity (Ulinnuha, et.al., 2013; Wodak \& Meyer, 2001). Intertextuality relates to the mindset carried from the text, while interdiscursivity relates to the ideology used by the subjects discussed in the text. The intertextuality related to the legalization of arak bali concerns how the Balinese people think about arak bali which related to Balinese culture. The following presentation is how arak bali has become part of Balinese culture and tradition.

One of the reasons for the legalization of arak bali because the arak bali as one of traditional liquor is part of Balinese culture which has become part of Hindu civilization. It has been said that liquor in Balinese society is part of a tradition that has been existed for quite a long time, which there is no prohibition against drinking liquor in Hinduism. Even liquor such as arak (rice wine), berem (traditional beverage made of fermented rice or tapioca), and tuak, must be present in every Hindu religious ritual. For example, the term metuakan refers to the activity of drinking tuak in tuak stalls or small stand in the village, and the metuakan tradition was only allowed for those who were adults. But, arak is not meant to be drunk at all, but is used for tetabuhan (one of the percussion instruments in Balinese gamelan which is used as an offering to Bhuta Kala) (Winata, 2009).
Beside of Bhuta Kala, tuak and arak are an important part of the implementation of the Buta Yadnya religious ceremony, which is a ceremony that aims to maintain the balance of nature so as not to interfere with human activities. In each of these ceremonies, there is an activity of spilling arak and tuak simultaneously onto the ground called metetabuh. This ceremony can be done on a small scale and a large scale. On a small scale, the ceremony is held in people's yards whenever deemed necessary, while on a large scale, the Buta Yadnya ceremony is held the day before Nyepi Day at major intersections in each district capital in Bali (Sarjana, 2020).

Arak and tuak is very important in the Buta Yadnya ceremony because it is found in the basis of yadnya in Hinduism (Suyatra, 2019). In the basis of the yadnya there is the Panca Makara, which consists of five basics in the yadnya. The five bases are Matsya which means fish. The fish used in the yadnya is gerang (anchovy). The second is Maituna which means having sex, where having sex produces a generation that keeps the tradition, in this yadnya it is symbolized by tipat or ketupat (steamed diamond shaped rice). Next, the third is Mantra. Every time someone perform a yadnya, he/she must use a mantra (spell), even if he/she pray in common language, it is still a mantra (spell). Fourth is Mudra, which means movement. Everyone knows that in yadnya Hindu religious ceremonies can not be separated from the dance that is displayed when piodalan (commemorate the birthday of the temple) at the temple. Lastly is Mada, which is drunkenness which is symbolized in Bali with tuak, berem, and arak (Suyatra, 2019).

Apart from being a religious function, arak bali also has a social function, namely building togetherness and strengthening kinship bonds in society. Arak is one of a kind of souvenir from residents who are brought to the homes of other residents who are carrying out religious ceremonial rituals other than rice and incense (Winata, 2009). Also, arak is often used as a symbol of the beginning of between in-law relations. When the two families of the bride and groom meet, the father of the bride and groom toasts and drink arak together to mark the family in question as close relatives. In addition, several villages in Bali do have a tradition of drinking arak and tuak which is held in conjunction with the implementation of religious ceremonies in the family, clan, or village environment. For example, the community tradition of drinking arak accompanies the metatah (tooth cutting) ceremony and wedding ceremonies in Karangasem Regency, Bali (Sarjana, 2020).

From this explanation, it can be concluded that 
the Balinese people's mindset towards arak bali cannot be separated from Hinduism which is a belief held by the Balinese people so that the beliefs that have been held for generations by the Balinese people towards arak bali can be categorized as intertextuality towards the legalization of arak bali as a traditional Balinese liquor. Meanwhile, the interdiscursivity towards the legalization of arak bali is related to the ideology of the Governor of Bali, I Wayan Koster towards arak bali. The following presentation explains how I Wayan Koster established arak bali as one of the traditional Balinese liquors which are considered legal.

As the Governor of Bali, I Wayan Koster is committed to developing and preserving Balinese culture and traditions. Balinese culture and traditions are not only related to religious rituals, but also related to culinary, one of which is a traditional Balinese liquor known as arak bali. Therefore, I Wayan Koster had the idea to legalize arak bali, which so far seems to be traded in secret and limited to certain circles. With this legalization, I Wayan Koster wants arak bali to become one of the traditional liquors in Indonesia that can be known throughout the world through tourists visiting Bali. From this explanation, it can be concluded that I Wayan Koster's commitment to arak bali shows I Wayan Koster's ideology as the Governor of Bali as well as the indigenous people of Bali to preserve Balinese culture and traditions, so that the ideology shown by I Wayan Koster can be categorized as interdiscursivity towards legalizing arak bali as Balinese traditional liquor.

\section{How Social Context Affected \& Influenced News Media}

The dimension of socio-cultural practice is an analysis at the macrostructural level. The interpretation of a text is strongly influenced by the social context that lies outside. Socio-cultural practices, such as the situational, institutional, and social levels affect media institutions and their discourse. Situational level, related to the production and context of the situation. Institutional level, related to the influence of institutions internally and externally. The social level relates to more macro situations, such as political systems, economic systems, and cultural systems of society.

Two headlines in data (4), Sudah jadi minuman legal, I Wayan Koster Berencana akan Adakan Festival Arak di Bali (it has become a legal liquor, I Wayan Koster plans to hold an Arak Festival in Bali), and data (6), Menyambut Legalisasi Arak Bali (Welcoming the Legalization of Arak Bali), is a form of discourse topicalization by focusing on the appreciation of the Governor of Bali, I Wayan Koster for the legalization of arak bali. A plan is designed to welcome the legalization of arak bali by holding the Arak Bali Festival. In this case, also, the dimensions of socio-cultural practices at the situational level have occurred, especially in the data (4) and (6).

Regarding socio-cultural practices at the institutional level, there are similarities in data (1), namely Sah! Arak Bali dan Brem Dilegalkan Gubernur Bali (It's Legal! Arak Bali and Brem were legalized by the Governor of Bali), while in the data (6), namely Sudah Menjadi Minuman Legal, Gubernur Bali Siap Adakan Festival Arak Bali (it has become a legal liquor, the governor of Bali is ready to hold a Arak Bali Festival). The two data have similarities even though it indirectly states that the Bali Regional Government has been able to legalize traditional liquors, but by saying that the Governor of Bali has been able to represent institutionally in the two titles. This can also be seen in data (1), (3), and (4) which mention the Governor of Bali I Wayan Koster in their respective online news media reports.

Socio-cultural practices at the cultural level are related to the cultural system of society. The culture of the Balinese people is so closely evident from the number of visits by domestic and foreign tourists. In this case, the relationship between culture and tradition cannot be separated from one another. Through the uniqueness of culture and tradition, it has a positive impact, which is maintaining the preservation of culture and traditions passed down by ancestors. In this case, drinking arak and tuak are a tradition in Bali which carried out in conjunction with the implementation of religious ceremonies in families, clans, and villages. One example is the metatah (tooth cutting) ceremony and weddings ceremony in Karangasem district. Previously, the local government was limited to use arak for traditional ceremonies, in other words, it was not allowed for commercial purposes. However, since the legalization of arak bali, both during religious ceremonies and for commercial purposes, liquors can be enjoyed by the public indefinitely.

\section{CONCLUSION}

Based on Fairclough's critical discourse analysis through three dimensions of discourse, it can be concluded that through the textual microstructural dimension, the six analyzed news headlines employed 1) selected diction or vocabulary that is focused on the word legal, both as a noun and verb; 2) grammatical units dominated by clauses; 3) syntactic functions dominated by information 
as the discourse's topicalization; and 4) a form of news in which emphasis is placed on the statement of the legalization of arak bali by the Governor of Bali, I Wayan Koster. Through the mesostructural dimension, as the intertextuality aspect, the Balinese people's mindset with respect to arak bali cannot be separated from Hinduism, the religion held by the majority of Balinese, reflecting how their beliefs and views of arak bali have been held and passed down for generations. Meanwhile, in the interdiscursivity aspect, Koster's commitment to arak bali reveals his ideology (as both the Governor of Bali and an indigenous person of Bali) of preserving Balinese culture and traditions. Finally, through the macrostructural dimension or the dimensions of socio-cultural practices, the headlines on the legalization of arak bali have occurred at the situational level, with Balinese people welcoming the legalization of arak bali. The effect of this has been for Koster to plan an arak bali festival as a form of promotion and preservation of Balinese culture. As such, with the legalization of arak bali, this traditional liquor may yet gain a place not only for the Balinese people, but for the people of the world, as well, who will be able to experience an Indonesian liquor on par and able to compete with those such as Japanese sake, Korean soju, or Chinese huangjiu.

\section{REFERENCES}

Alfianti, Luffita. (2018). Upaya Pemerintah Daerah dalam Pengendalian Produksi Minuman Beralkohol Tradisional. YURIDIKA, Volume 33 No. 1, Januari 2018, pp. 93-107. DOI : 10.20473/ydk.v33i1.5671.

Alzeer, J. \& Hadeed, K. A. (2016). Ethanol and its Halal status in food industries. Trends in Food Science \& Technology 58 (2016), pp. 14-20. http://dx.doi. org/10.1016/j.tifs.2016.10.018.

Cinti, P.I.R. (2020). Mengenal Arak Bali yang Baru Dilegalkan. (Online). Retrieved on 1 April 2021 from https://travel.detik.com/domesticdestination/d-4888844/mengenal-arak-bali-yangbaru-dilegalkan.

Dahlan, Dahi. (2010). Tribunnews.com dan Bendera Tribun Network. (Online). Retrieved on 1 April 2021 from https://www.tribunnews.com/tribunners/2010/03/23/ tribunnews.com-dan-bendera-tribun-network

Darma, Y.A. (2013). Analisis Wacana Kritis. Bandung: Yrama Widya.

Fairclough, N. (1995). Language and Power. London and New York: Longman, 1995

Fatmawati, R. (2018). Tradisi Minum Tuak di Desa Tegalrejo Kecamatan Merakurak Kabupaten Tuban. Unpublished bachelor thesis. Surabaya: Universitas Islam Negeri Sunan Ampel.
Indrayati, Putu Ayu, et.al. (n.d.). Persepsi Produsen Arak di Desa Merita, Karangasem Mengenai Bahaya Keracunan Arak Oplosan yang Mengadung Metanol yang Dapat Mengancam Kesehatan dan Pariwisata di Bali. (PDF).

Khusnaini, P. M. (2016). Pandangan Tokoh Agama dan Tokoh Masyarakat terhadap Peredaran Jual Beli Tuak di Kabupaten Tuban Jawa Timur. Unpublished bachelor thesis. Malang: Universitas Islam Negeri Maulana Malik Ibrahim.

Mahsun. (2014). Metode Penelitian Bahasa: Tahapan Strategi, Metode, dan Tekniknya. Jakarta: PT Raja Grafindo Persada.

Mustofa, Ali. (2018a). HOT NEWS!! Koster Akan Legalkan Arak Bali. (Online). Retrieved on 1 April 2021 from https://radarbali.jawapos.com/ $\mathrm{read} / 2018 / 11 / 14 / 103633 /$ hot-news-koster-akanlegalkan-arak-bali.

Mustofa, Ali. (2018b). Seriusi Legalisasi Arak Bali, Koster Segera Lakukan Riset dan Kajian. (Online). Retrieved on 1 April 2021 from https://radarbali.jawapos.com/ $\mathrm{read} / 2018 / 12 / 26 / 110384 /$ seriusi-legalisasi-arak-balikoster-segera-lakukan-riset-dan-kajian.

Panggabean, S. M. (2015). Analisis Konsumsi Tuak pada Peminum Tuak di Desa Lumban Siagian Jae Kecamatan Siatas Barita Kabupaten Tapanuli Utara Sumatera Utara Tahun 2015. Unpublished bachelor thesis. Jakarta: Universitas Islam Negeri Syarif Hidayatullah.

Perpustakaan UNAND. (2018). Tribunnews.com Website Lokal Paling Diminati Netizen. (Online). Retrieved on 1 April 2021 from https://pustaka.unand.ac.id/ berita-dan-peristiwa/item/177-tribunnews

Prasetya, Rizki. (2020). Arak Bali Legal, Ngasih Perspektif Baru Memandang Alkohol. (Online). Retrieved on 1 April 2021 from https://mojok.co/rzp/pojokan/ arak-bali-legal-ngasih-perspektif-baru-memandangalkohol/.

Ramadhian, N. (2020). Apa Itu Arak, Minuman Beralkohol Khas Bali yang Kini Legal?. (Online). Retrieved on 1 April 2021 from https://travel.kompas.com/ read/2020/02/10/220200627/apa-itu-arak-minumanberalkohol-khas-bali-yang-kini-legal?page=all.

Rasyid, Shani. (2020). Punya Ciri Khas, Ini Ide Jurnalisme Ala Jakob Oetama yang Dikenang UGM. (Online). Retrieved on 1 April 2021 from https://www.merdeka. com/jateng/punya-ciri-khas-ini-ide-jurnalisme-alajakob-oetama-yang-dikenang-ugm.html?page=all

Riskiyani, S., et.al. (2015). Aspek Sosial Budaya pada Konsumsi Minuman Beralkohol (Tuak) di Kabupaten Toraja Utara. JURNAL MKMI, Juni 2015, pp. 76-85.

Rizky, Purnama Ayu. (2020). 4 Alasan Pentingnya Legalisasi Arak Bali. (Online). Retrieved on 1 April 2021 from https:/www.matamatapolitik.com/4-alasan- 
pentingnya-legalisasi-arak-bali-original-listiclepolling/.

Rogers, Tony. (2019). What Is a Breaking News Story? Characteristics and Professional Tips for Journalists. (Online). Retrieved on 1 April 2021 from https:// www.thoughtco.com/what-is-a-breaking-newsstory-2073757

Sarjana, I Made. (2020). Penelitian Jelaskan Mengapa Legalisasi Arak Bali Dibutuhkan Masyarakat. (Online). Retrieved on 1 April 2021 from https:// theconversation.com/penelitian-jelaskan-mengapalegalisasi-arak-bali-dibutuhkan.

Sudharma, K.J.A., et.al. (2020). Arak Sebagai Produk Lokal Dalam Mendukung Desa Tri Eka Buana Menuju Desa Wisata. JMM (Jurnal Masyarakat Merdeka), Volume 3 Nomor 1, Mei 2020, pp. 7-14.

Sudut Story. (2020). Cara Buat Arak Bali. (Online). Retrieved on 1 April 2021 from https://www.sudutstory.com/ tag/cara-buat-arak-bali/\#: :text=Arak\%20Bali $\% 20$ merupakan $\% 20$ minuman $\% 20$ alkohol,20\%2C\%20 hingga $\% 2040 \% 20$ persen $\% 20$ alkohol.
Sukadana, I G.K. \& Tenaya, I G.N.P. (2016). Pengaruh Penggunaan Arak Bali sebagai Bahan Bakar pada Mesin Empat Langkah dengan Rasio Kompresi Bervariasi. Flywheel: Jurnal Teknik Mesin Untirta, Volume II Nomor 1, April 2016, pp. 1-8.

Suyatra, I Putu. (2019). Dalam Hindu, Minuman Beralkohol Tak Dilarang, Takarannya Diri Sendiri. (Online). Retrieved on 1 April 2021 from https://baliexpress. jawapos.com/read/2019/11/06/164756/dalam-hinduminuman-beralkohol-tak-dilarang-takarannya-dirisendiri.

Ulinnuha, R., et.al. (2013). Critical Discourse Analysis: Theory and Method in Social and Literary Framework. Indonesian Journal of Applied Linguistics, Vol. 2 No. 2, January 2013, pp. 262-274.

Winata, I Nyoman. (2009). Miras dalam Tradisi Masyarakat Bali. (Online). Retrieved on 1 April 2021 from https:// balebengong.id/miras-dalam-tradisi-masyarakatbali/.

Wodak, R. \& Meyer, M. (2001). Methods of Critical Discourse Analysis. London: Sage. 